\title{
Going for Gold: Transitional Livelihoods in Northern Ghana
}

\author{
Gavin Hilson $^{a^{*}}$, Richard Amankwah ${ }^{\mathrm{b}}$ and Grace Ofori-Sarpong ${ }^{\mathrm{b}}$ \\ ${ }^{a}$ Faculty of Business, Economics and Law, University of Surrey, Guildford \\ GU2 7XH, United Kingdom \\ ${ }^{b}$ Mineral Engineering Department, University of Mines and Technology, P.O. Box 237, \\ Tarkwa, Ghana
}

\section{Acknowledgements}

Funding for this research was provided by the British Council, under DelPHE project \#792. The authors are grateful for the assistance provided by the Wa District Officer of the Minerals Commission of Ghana, and would like to thank all of the people interviewed in Kui for participating in interviews, in particular, the Kui Wura, Alhaji Alhassan.

\footnotetext{
*g.m.hilson@ surrey.ac.uk
} 


\begin{abstract}
This article critically reflects on what impact a supported and formalized artisanal and smallscale mining (ASM) sector could have in Northern Ghana, where poverty is deeply-rooted, the outcome of decades of government neglect. Since country independence in 1957, numerous attempts have been made to improve the living standards of the populations in the country's North but deteriorated human resource bases and shortages of infrastructure have limited their effectiveness. A recent upsurge in ASM activity, however, has catapulted the region on to another - previously unimaginable - growth trajectory entirely. As findings from research carried out in the township of Kui in Bole District of the country's Northern Region illustrate, ASM has injected considerable wealth into many of Ghana's Northern localities, in the process, helping to stabilize their economies and in the process, alleviating the hardships of tens of thousands of farm-dependent families. The intensification of support to, and the formalization of, ASM, could prove to be an important step toward eradicating a poverty problem that has plagued this region of sub-Saharan Africa for more than a century.
\end{abstract}

Keywords: Artisanal and small-scale mining (ASM); Ghana; poverty; livelihood diversification; agriculture 


\section{Introduction}

Over the past two decades, artisanal and small-scale mining (ASM) - low tech, labour-intensive mineral extraction and processing - has expanded rapidly in many corners of sub-Saharan Africa. Whilst there is some debate over the precise role this sector of industry plays in the environments where it is now widespread, there is broad agreement in the literature that it is one of the most important rural nonfarm activities in the region today. Most of the people found working in ASM communities across sub-Saharan Africa are subsistence farmers who have 'branched out' in order to obtain supplementary incomes. Based on recent estimates, there could be upward of 10 million people employed directly in ASM in the Democratic Republic of Congo, Ghana, Tanzania and Mozambique alone.

In these countries and a number of other rural stretches in sub-Saharan Africa, ASM is largely 'poverty-driven', providing immediate income relief to scores of impoverished families. The evidence in support of this is overwhelming: over the past two decades, countless studies (e.g. Fisher 2007; Banchirigah 2008) have emerged which capture how ASM, by generating direct employment and spawning downstream industries, has brought stability to scores of fragile, impoverished rural localities. This has led to calls (e.g. Siegel and Veiga 2009; Maconachie and Hilson 2011) for donors and host governments to formalize the sector and provide assistance to its operators. But in a region of the world - sub-Saharan Africa - where smallholder agricultural development has long been the centrepiece of rural economic development strategies, the idea that a supported ASM sector could alleviate significant hardship has, not surprisingly, encountered some resistance in policymaking circles. This is particularly unfortunate for Sahelian communities, where, because of harsh climatic conditions and short growing seasons, any agricultural-led poverty alleviation strategy is bound to have a limited impact. In these arid localities, a large number of which 
are remote and disconnected from large commercial centres and country capitals, an infusion of more dynamic rural development strategies is desperately needed.

Nowhere has this been more evident than in Northern Ghana, where a combination of decades of neglect from government, repeated application of inappropriate development interventions and an eroded agricultural base, has caused significant poverty. This region of the country has long been victimized by outmigration, struggling mightily to retain the human resource base needed to catalyze development. Over the past decade, however, its socioeconomic landscape has changed dramatically, in large part because of the rise - and some cases, re-surfacing - of small-scale gold mining. The sector's activities have provided a much-needed economic boost in the region, generating earnings for numerous impoverished farm families, which now find themselves in a position to purchase crucial agricultural inputs and by doing so, have managed to increase production on their plots and improve their food security situations dramatically. Perhaps most importantly, the emergence of ASM has reduced outmigration and in some cases, has even attracted numerous skilled and semiskilled people from other areas of the country. The development catalyzed by a booming ASM sector has put many Northern Ghanaian localities in a position to consider mediumterm development plans for the first time.

The purpose of this article is to critically reflect on what impact, developmentally, a more supported and formalized ASM sector could have in Ghana's impoverished Northern Territories. The analysis draws upon pilot research carried out in the township of Kui in the Bole District in the Northern Region of the country, where vast quantities of gold have been discovered and worked over the past 10-15 years. After briefly reviewing the literature on livelihood diversification in rural sub-Saharan Africa and 'locating' ASM in this body of scholarship, the paper explores how the emergence of subsistence gold panning in Kui and surrounding localities has changed the socio-economic dynamics of Northern Ghana. Whilst 
ASM activities have provided a much-needed - and largely-unanticipated - economic boost in localities such as Kui, in the short-term, the launch of an ASM-led poverty development strategy in Northern Ghana may be highly unrealistic, given the radical change in policy mindset that would be required to engineer such a move.

\section{Livelihood Diversification in Arid African Environments}

The burgeoning literature on livelihood diversification in rural sub-Saharan Africa tells so much yet reveals so little. On the one hand, the series of reviews produced on the subject in the 1980s and 1990s (e.g. Bryceson 1996; Ellis 1998) offer a glimpse of the breadth of economic activity found in many rural stretches of the region at the time, illustrating how selected households responded to major economic and political changes. In addition to helping to dispel the commonly-held belief that 'everyone in Africa wants to farm', this body of literature identified some important nonfarm activities into which rural families have 'branched out'; put forward possible motivations for diversification, disaggregating these drivers into a series of 'push' and 'pull' factors; and speculated on the impacts diversified income portfolios have had on households.

On the other hand, these critiques proved to be little more than timely reminders of a phenomenon - rural livelihood diversification - that has engulfed the region for decades. Most simply rehash many of the key observations made by leading African anthropologists in the 1950s, 1960s and 1970s. They convey very generic messages, despite drawing upon experiences from a wide range of countries, including Malawi, Uganda and Burkina Faso, each of which has very unique socio-economic characteristics and cultural dynamics. In fact, this body of literature is littered with numerous ambiguities, generalizations and inconsistencies, and provides very little fresh insight on the livelihood diversification 
phenomenon in rural sub-Saharan Africa today. These shortcomings are a cause for concern: with the effects of debilitating structural adjustment programs having finally been recognized, the issue of livelihood diversification in sub-Saharan Africa - and more broadly, the adaptation strategies of the region's rural households - has started to gain some traction in policymaking and donor circles. An incomplete and unrepresentative body of scholarship, therefore, runs the risk of misinforming policy and development interventions aimed at lifting vulnerable rural groups out of poverty.

These shortcomings become clear when attempting to diagnose - even at a superficial level - why families elect to 'branch out' into nonfarm activities in localities such as Kui. Perhaps the most significant problem is the acute shortage of reliable baseline demographic information on hand: the census data fail to provide an accurate overview of population movements, as well as details about the livelihood strategies and preferred rural nonfarm activities of 'diversified' households. For example, the information used in a landmark study on rural livelihood diversification in Southern Mali (Abdulai and CroleRees, 2001) was collected more than five years prior to publication, during the 1994/95 and 1995/96 farming seasons. A similar study on rural livelihood diversification carried out in neighbouring Burkina Faso, published nearly a decade earlier (Reardon et al., 1992) also made use of old survey data gathered over four harvest years (1981/82-1984/85). Even many of the recent livelihood studies carried out in locations not too far from Kui itself (see e.g. Yaro 2006; Laube et al. 2012) fall short of providing a representative picture of local livelihood dynamics. These studies, though important, also present outdated information which, if used by policymakers, could yield inappropriate poverty alleviation strategies.

This leads to a second area of concern: namely, failure to recognize ASM's importance, economically, in sub-Saharan Africa. Despite fast becoming the most important nonfarm activity in many rural stretches of the region, ASM is barely acknowledged in the 
literature on livelihood diversification (e.g. Bryceson 1996; Ellis 1998; Barrett et al. 2001). Unlike other rural nonfarm activities, such as transport, beer brewing and craft-making, this body of scholarship has not yet created a 'space' for this activity. Sub-Saharan Africa is today the location of a vibrant ASM sector, which provides direct employment to tens of millions of men, women and children (ILO, 1999). Over the past 10-15 years, however, it has experienced meteoric growth, which could help to explain its absence from many of the early landmark reviews of livelihood diversification in the region, as well as its continued understated importance in the more recent literature on the subject. Referring back to the aforementioned studies, in the Sikasso Region of Mali, which harbours the study locations where Abdulai and CroleRees (2001) claim that 'the primary activities of households...include farming, dominated by the production of coarse grain (sorghum, millet and maize), rice, cotton and livestock (mainly cattle)' (p. 440), there are now over 200,000 artisanal gold panners (Keita, 2001); there are today hundreds of thousands of small-scale gold miners found in sections of the Sahelian, Sudanian and Guinean zones of Burkina Faso (Gueye 2002; Jaques et al. 2006) where Reardon et al. (1992) carried out their research; and, sandwiched between the Kassena-Nankana, Bongo and Bolgatanga Districts, where Yaro (2006) and Laube et al. (2011) collected detailed survey data on farmers' livelihoods, is Talensi-Nabdam District, home to a small-scale gold mining population of over 20,000 men, women and children (Hilson, 2010).

A third shortcoming is that there is no real sense in this literature of where diversification is most critical to the survival of rural Africans. As indicated, the research undertaken on this subject to date draws upon experiences from a range of populations facing very different circumstances, including individual households in semi-arid environments such as Niger and Burkina Faso (e.g. Batterbury 2001; West 2009); the nomadic communities of East Africa (e.g. Little et al. 2009); and groups inhabiting lush environments with lengthy 
growing seasons (Ellis and Bahiigwa 2003; Bigsten and Tengstam 2011). At each location, a family's decision to diversify is governed by very unique sets of factors. The economic impact of any move, as well as the importance of doing so, also varies depending upon location. Yet, the literature does little more than disaggregate drivers for diversification into broad categories of 'push' and 'pull' factors, in turn, painting a very homogenous picture of what is clearly a dynamic issue. Using seasonality as an example, Ellis (2000) casts light on how different the context for diversification can be for two categories of people:

...diversification that obeys different opportunities in different seasonal labor markets does not require risk as an explanatory argument for its occurrence. For example, an opportunity to take temporary employment in a mango juicing plant at the peak of the mango harvesting season does not need to be predicated on the risk status of the household to make sense as a diversification option...To take another extreme example, a farm household producing a single annual crop of maize would effectively gain its entire annual income at the time of the maize harvest. [p. 58-59]

For localities such as Kui, which has a savannah-type climate and therefore limited agricultural potential, harbours few established industries and is disconnected from Ghana's major urban centres, most movement into ASM is likely to be of a 'distress-push' nature. These are situations where, 'in the face of incomplete insurance markets, income diversification is viewed as a household strategy to minimize income variability and ensure a minimum level of income' (Wouterse and Taylor, 2008, p. 626), and/or where 'mounting [environmental] pressures' in the form of 'low rainfall amounts, high rainfall variability, high temperatures, aridity and droughts...force pastoralists to diversify their livelihood portfolios beyond their traditional reliance on livestock' (Wren and Speranza, 2010, p. 752). The rich body of literature on livelihood diversification in Sahelian environments certainly provides some idea of the circumstances underpinning individual employment-related decisions in localities such as Kui. As Elmqvist and Olsson (2006, p. 168) explain, 'Drylands comprise 
some of the most dynamic regions of the world and diversification can be imperative for the livelihoods and survival of the population'. In these settings, there is little disputing that poorer households have the most to gain from diversification (after Thornton et al., 2007). With crops being so vital to the survival of the household, here, most movement into other activities takes place during the dry season (Elmqvist and Olsson, 2006).

The generic conclusions drawn on the drivers and implications of rural livelihood diversification in sub-Saharan Africa have, in recent years, sparked some critical debate in the literature, a large share of which has focused on pastoral communities and/or Saheliantype environments such as Kui. One of the more significant observations was made by Pedersen and Benjaminsen (2008, p. 44), who asked: 'while diversification of livelihoods might be a good idea for most rural African households...under what conditions is it good advice?' The authors question whether, in the case of certain pastoralist groups, diversification is capable of alleviating family-level hardship altogether, pointing out that the costs of combining different modes of livelihood are large and potentially too much to overcome for an individual household. These circumstances, they further argue, potentially make specialization of production units and trade a more viable option. Drawing upon research conducted in four different pastoral communities in Southern Africa, Thornton et al. (2007) reached similar conclusions, using their findings to underscore 'the importance of understanding different households' objectives and attitudes', as well as to argue that whilst 'all the case studies can be looked at within a common analytical framework, no common household model can be applied across all sites and all household types, as the objectives associated with livestock management range from profit maximisation to the sociocultural and steadfastly noneconomic' (p. 470). These observations reinforce claims made earlier: of the importance of not drawing sweeping conclusions about the drivers of livelihood 
diversification in rural sub-Saharan Africa, and the need to assess situations on a case-by-case basis, something which, to date, scholars have failed to do.

Such analyses have helped to contextualize one significant issue a number of scholars have explored - albeit, rather superficially - which has application to Kui and other ASM settings: the ability of households to diversify their income portfolios. There is now a vibrant debate in the literature on 'barriers to entry' in the livelihoods literature, the consensus being that poorer households are far more challenged when it comes to diversifying. The topic was initially covered in some level of detail by Barrett et al. (2001), who observed that 'poorer households haven't the resources to overcome the skills and capital entry barriers that enable the farm and skilled non-farm strategy to yield such high rates of real return and to keep entry rates low' (p. 377). Several scholars (e.g. Smith 2001; Fabusoro and Sodiya 2011) openly support this position. The discussion on 'barriers to entry' builds upon the debate on access to resources, which Berry $(1989$, p. 41) first examined at length:

People's ability to generate a livelihood or increase their assets depends on their access to productive resources and their ability to control and use resources effectively. Access depends, in turn, on participation in a variety of social institutions, as well as on material wealth and market transactions...Since pre-colonial times, Africans have gained access to land, labour, and capital for agricultural production both through exchange and through membership and status in various social units. Rights to occupy, hunt, administer or cultivate land, for example, were often contingent on membership or status in a compound, descent group or community.

In the case of ASM, however, with there being so many people who stand to benefit from its growth, access to resources - at least in the case of sub-Saharan Africa - is rarely an issue, at least in the conventional sense. This is especially the case in arid localities such as Kui, where there are few economic opportunities. 
Gold, Subsistence Agriculture and Transitional Livelihoods in Northern Ghana: The Case of Kui

A combination of factors has, in Rostovian terms, prevented Northern Ghana from meeting the requisite pre-conditions for 'take-off'. The recent discovery - and in some cases, 're-discovery' - of gold, however, has changed its fate dramatically. In many towns in Northern Ghana, ASM has facilitated a radical reorientation of livelihoods, providing a much-needed source of hope to scores of subsistence farm families, in the process, helping to stabilize hitherto fragile economies. The case of Kui, a village located in the town of Tinga in Bole District of the Northern Region of the country (See Figure 1), captures the essence of this transformation.

Figure 1: Location of Kui, Bole District, Northern Region

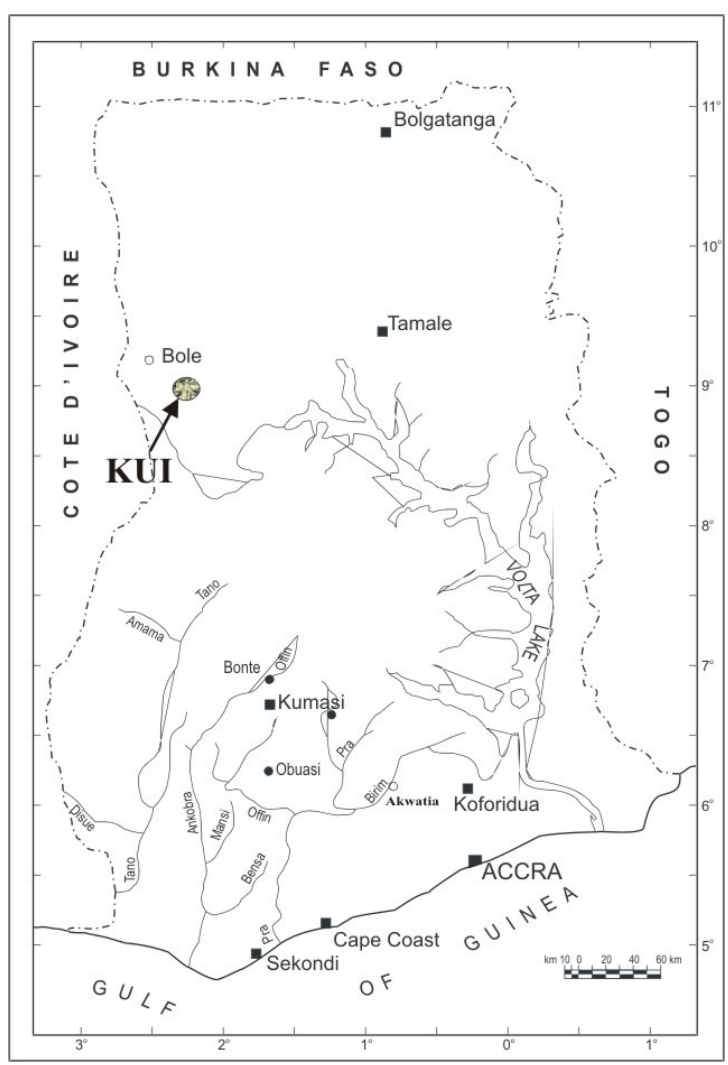


Kui has a savannah climate. Its landscape is characterized by scattered shrubbery, withering trees, parched waterbodies and rampant bush fires, conditions typical of environments with extended dry seasons. Most of the village's 7000 occupants consider themselves 'farmers first', although these harsh climatic conditions have long confined their production to a subsistence level. The emergence of small-scale gold mining over the past four years, however, has improved economic prospects in the town considerably, helping to nourish farming activities; spawned a series of downstream trades such as blacksmithing and welding; and catapulted many families on to a trajectory of earning previously unimaginable. To broaden understanding of these dynamics and the growing importance of ASM in Kui more specifically, interviews were conducted with families based in the town, using a snowballing technique. Overall, 130 individuals were interviewed, including the Kui Wura ${ }^{1}$ and three community 'elders'. Of the 126 people interviewed from the general populace, 86 were male and 40 were female, a balance which is fairly representative of the gender ratio in Kui (60 per cent male, 40 per cent female). The modal age of respondents was 20-30 years (64 per cent and 50 per cent of females and males, respectively, were in this age bracket), a reflection of the current population pyramid of the town, where close to 80 per cent of inhabitants are migrants under the age of 30 . This section of the paper reports preliminary findings from this research. The analysis captures how ASM is bringing positive change to the lives of many families in Kui, in the process providing a glimpse of what a formalized and supported artisanal gold mining economy could deliver, economically, to many of Ghana's impoverished northern townships.

\footnotetext{
${ }^{1}$ The chief of Kui.
} 
When the events of the past century are taken to account, it becomes clear why the emergence and resurgence of ASM activity in Northern Ghana is potentially a 'blessing'. To gain a better appreciation of what impact this activity could have in impoverished towns such as Kui, it is instructive to first review these events.

Few areas of sub-Saharan Africa have been impacted by climatic conditions, developmentally and economically, as much as Northern Ghana: a consequent unproductive agricultural base, along with a sparse population, has inhibited its growth considerably. As explained by Plange (1979a, p. 5), during the decades following country independence in 1957, social scientists and policymakers began to recognize this: that the 'relative underdeveloped and backward character' of Northern Ghana was, indeed, a result of a combination of 'natural processes'. Poor soil quality, lengthy dry seasons and a lack of natural resources in particular were recognized at the time as having a crippling effect on Northern Ghanaian 'peasants'. But the glaring developmental needs of Ghana's North continued to be ignored, in large part because - rather ironically - of these very reasons: that because it is resource-poor and under-populated, and was seen to have few economic prospects, the region should not receive priority aid.

This view emerged during the British colonial period. It was set in motion in policy by Sir Frederick Hodgson, Governor of the Gold Coast from 1898 to 1900, who was quoted as saying:

I cannot too strongly urge the employment of all available resources of the Government upon the development of the country south of Kintampo...I would not at present spend upon the Northern Territories - upon in fact the hinter-land of the Colony - a single penny more than is absolutely necessary for the suitable administration and the encouragement of the transient trade. [Kimble, 1971, p. 533-34] 
Subsequent governors of the Gold Coast Colony continued to exercise an isolationist policy toward the Northern Territories. Notable among these was Sir Hugh Charles Clifford, who, during his tenure (December 1912-April 1919), advanced a number of arguments 'against expenditure for economic development in the Northern Territories', including the views that the population was not 'having regard to the area it inhabits'; transport to towns and cities as challenging and expensive; and that Northern towns offer no 'natural advantages' for agricultural production over the colony's more populous, more accessible southern territories (Ladouceur, 1979, p. 46).

Years of neglect has produced what the World Bank recently today describes as Ghana's 'North-South Poverty Divide'. The effects of decades of dismissing the developmental needs of the Northern Territories, which again, became visibly obvious long before country independence in 1957, posed a challenge to Kwame Nkrumah's Government. Reflecting on this problem over four decades ago, Plange (1979a, p. 13) pointed out that 'By the end of 1950, the north trailed behind the southern region both in terms of commerce, population enrolled in schools, as well as population with some education, and in other areas of social services, the region was also largely neglected'. Independence, however, would bring very little change. As explained by Yaro (2010), the Nkrumah Government passed the Administration of Land Act, 1962 (Act 123), with consequential Executive Instruments 87 and 109 of 11 July 1963, which vested all northern lands in the president (i.e. made them public lands). These laws granted Nkrumah ready-access to the north at a low cost, and enabled land to be appropriated, without compensation, to accommodate the state's 'vision' of rural development, a policy which would benefit influential people more so than poor peasants. The move made in 1992 in an attempt to unravel this process, by transferring control of all lands in the north to traditional authorities, has failed to bring poverty in the North to a halt. In fact, it appears that the situation has worsened: statistics reveal that 
between 1992 and 2006, the number of poor dropped by two million in Ghana's Rural South but increased by 0.9 million in its Rural North (World Bank, 2011).

Ghana's censuses capture the seriousness and breadth of the poverty plaguing its Northern Territories. The data itself, however, are heavily outdated, which makes identifying specific livelihood diversification patterns difficult. As indicated, drawing conclusions about the motives behind rural livelihood diversification from obsolete data will almost certainly yield inappropriate policy interventions. There is little disputing that the country's most recent Ghana Living Standards Survey (Ghana Statistical Services, 2008) paints a broad and accurate overview of the demographics of the impoverished North. But at the same time, it fails to provide the information needed - specifically, data on peoples' lives, attitudes toward employment and survival strategies - by policymakers and donors to lift individual families out of poverty. Another important issue that has been overlooked is clarification of how persistent poverty has affected peoples' mindsets. Decades of neglect have put many rural families in the North of Ghana in perpetual 'survival mode'. Generations of hardship brought about by a lack of economic development and harsh climatic conditions seem to have conditioned Northerners to prioritize food production, which, at times, has delayed their entrance into the wage economy.

This is particularly evident in the country's Northern Region, where Kui is located. Here, food accounts for 65.2 per cent of household expenditure (second only to the Volta Region) and where, although 92 per cent of rural families produce maize, only 27 per cent sell any (Ghana Statistical Services, 2000, 2008). In Kui itself, as indicated, there is a sense that people consider themselves 'farmers first', and that despite its growing currency as an income-earning activity, ASM is still viewed largely as a complementary livelihood activity. This message was conveyed during a number of interviews: 64 per cent of those consulted identified farming as their preferred occupation. However, all indicated that harsh climatic 
conditions, an extended dry season and a lack of agricultural inputs have left people with little choice but to prioritize ASM activity when it comes to securing wages. The story told by one interviewee, 'Awudu', summed up the reasoning behind Kui's rapidly-changing livelihood dynamics:

I love farming more than galamsey. ${ }^{2}$ However, the monetary rewards are better and faster with ASM, hence the shift. For farming, I have to wait for almost a year before getting money.

The message relayed in interviews was that ASM has become the principal income-earning activity in Kui, overtaking farming, which for most of the town's families, is no longer perceived as a reliable source of disposal earnings. It is rather mainly undertaken solely to supply food for the household. This even appears to be the case with the Tinga Wura, who explained in an interview that despite having a large farm, he harvests strictly to satisfy the needs of his household, and that ASM is his main source of 'ready-cash'.

With there being so few other viable sources of employment available in Kui and adjacent localities, ASM has - almost by default - become the inevitable and unavoidable end destination for scores of people who, in other settings, would have likely gained educational qualifications. Among those surveyed, 37 per cent reported that they had never been enrolled in an educational institution, 50 per cent had a basic level of education, and only 10 per cent and 0.8 per cent, respectively, had high school and tertiary education (Figure 2). This mirrors the general trend captured by the most recent Ghana Livings Standards Survey (Ghana Statistical Services, 2008), which revealed at the time of surveying that in the country's three northern regions (Northern Region, Upper East Region and Upper West Region), less than 70 per cent of children aged 6 to 11 are attending school. Most individuals interviewed cited financial constraints as the main reason behind their decision to end their schooling after

\footnotetext{
${ }^{2}$ A local term for illegal mining, the literal translation of which is 'gather them and sell'.
} 
primary school or Junior Secondary School (JSS). At present, however, a combination of low-skilled ASM work and smallholder farming is proving to be the perfect tonic for alleviating hardship in a town made up of 'early school leavers' and where there are few other viable employment alternatives. Moreover, and as will also be explained, this 'mix' of activity could help to reverse decades of out-migration, which for decades, has deprived the North of Ghana of the skill-base needed to 'kick-start' development.

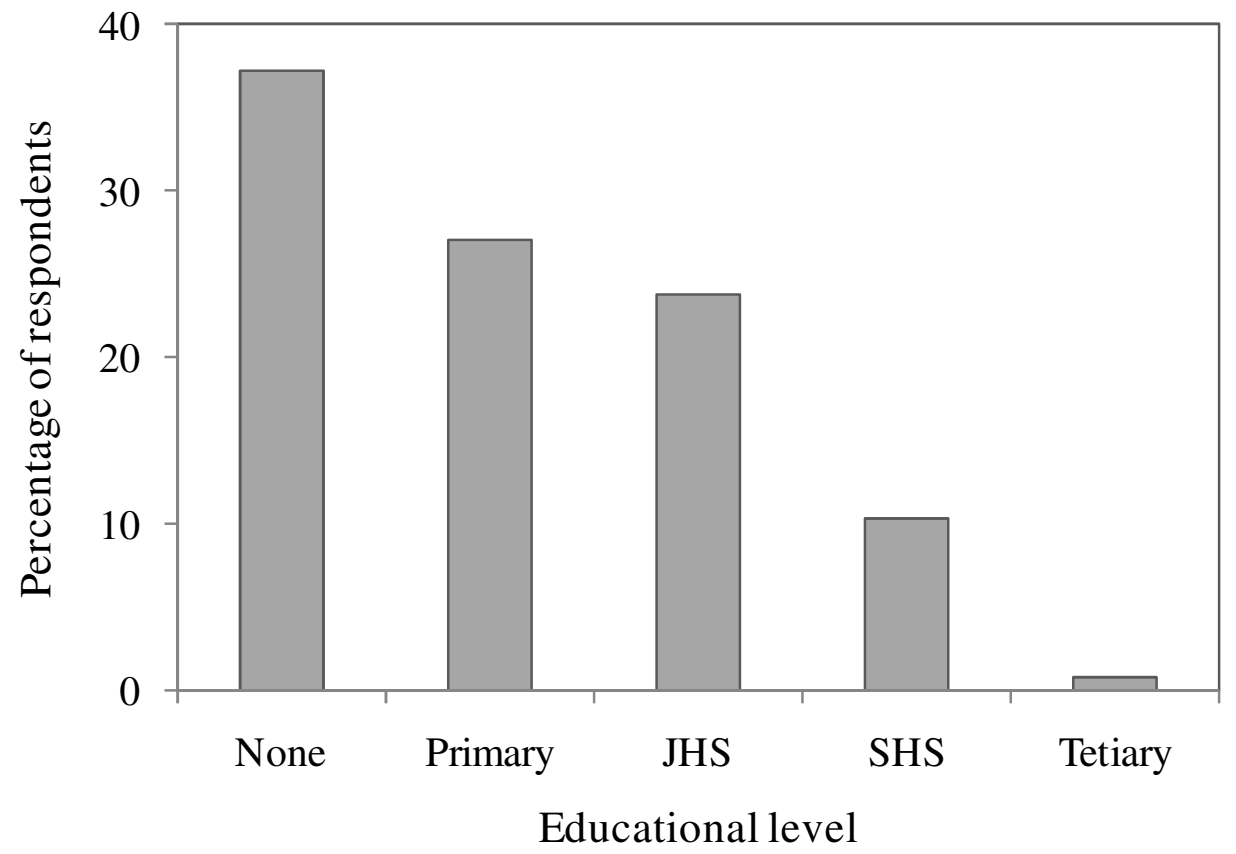

Figure 2: Educational levels of respondents

\section{Livelihood diversification in Kui}

How have subsistence families in Kui and surrounding villages managed to 'branch out' into ASM so easily? As indicated earlier, the general message presented in the literature is that poor rural African families wishing to diversify their livelihood portfolios simply lack the financial muscle to do so (Barrett et al. 2001; Wouterse and Taylor 2008). Experiences in 
the ASM sector, however, tell a much different story. Reflecting on the case of alluvial diamonds, Snyder (2006, p. 950) pointed out, perhaps slightly exaggeratedly, that 'to mine alluvial diamonds, a pick, shovel, sieve, and sweat are usually the only requirements'. In fact, the belief that moving into ASM is a relatively straightforward process has long resonated in policymaking circles. Many donors now also share this view, most notably the World Bank, which takes the position that '[ASM] offers a livelihood choice for many people in fragile, rural economies (where other employment options are limited) because the barriers to entry are low, requiring relatively limited financial, educational, and technological investment' (World Bank, 2005, p. 12). Recent research (e.g. Banchirigah 2008; Maconachie and Hilson 2011) suggests that this is indeed the case: that ASM provides a host of skilled and unskilled employment opportunities.

This assumes, however, that mineral rights and/or land rights are of little consequence in the settings where activities take place. Neither appears to be an inhibiting factor in Kui. Whilst the Ghanaian Government has designated the town a 'no-go' area for small-scale mine licensing because it falls within the catchment zone of the Bui Dam, ${ }^{3}$ numerous families have taken advantage of a low regulatory and police presence to undertake unlicensed small-scale gold mining and processing alongside their farming activities. ${ }^{4}$ Here, securing access to gold-mineralized land does not appear to be very difficult. It was explained during an interview with one community 'elder' that a transaction can be made 'by verbal application to the elders [of the community]', who will conduct an interview to determine the motive for

\footnotetext{
${ }^{3}$ The Bui Dam, which is currently under construction, is a 400MW hydroelectric project located at the southern tip of the Bui National Park, on the border of the Brong-Ahafo Region and Northern Region.

${ }^{4}$ As summarized by Aryee et al. (2003), there is a registration process that must be followed if one wishes to obtain a license - and thus operate legally - for small-scale mining. It is a cumbersome process which requires costly payments and several visits to ministries located in Accra.
} 
land acquisition; this, it seems, is a formality. Once mining commences, operators are expected to pay a small royalty to the Kui Wura.

A movement into ASM in Northern Ghanaian communities such as Kui bodes well for all parties involved. For the most part, local families have embraced the idea of 'branching out' into ASM because it is seen as a low-risk income-earning option and a perfect complement to the subsistence farming activities they have no intention of abandoning. The message relayed during interviews with residents was that the ASM activity now prevalent in the town has enabled them to retain their 'farm-first' lifestyles which, again, is important culturally, as well as psychologically, given the food security issues many have long faced. In line with the reasoning of the Kui Wura, most of the individuals interviewed reported that a movement into ASM activity was essential to the survival of their farms: the extra wages earned from the move are used to acquire crucial agricultural inputs such as insecticides and fertilizers. This symbiosis, however, even applies to those who do not have diversified livelihood portfolios - namely, individuals who undertake either farming or ASM. Many of the people interviewed who engage solely in the former explained that they have forged partnerships with miners, who provide them with badly-needed capital for their farms. It was explained that agreements of this nature have yielded larger harvests, the proceeds from which are shared. Table 1 provides a summary of occupational details of those surveyed.

Unlike in the South of Ghana, where many people see ASM as a destructive activity, in Northern villages such as Kui, movement into the sector is viewed very positively. The evidence points to there being two reasons why the Kui Wura and village elders would embrace a move into ASM. The first is that there is little chance of it overtaking farming as the main livelihood activity in Kui because climatic conditions restrict production and ultimately, relegate it to 'complementary' position in this context. Knowledge that ASM has 
its limitations has helped to alleviate concerns about the industry potentially eroding the township's 'farm-first culture'. It was explained during interviews with elders that even the vast majority of individuals who have migrated to Kui over the past three years purposely to engage in ASM have had little choice but to add farming to their livelihood portfolios or to forge partnership with local farmers. As the long dry season and low water availability prevents processing of large tonnages of ore at any given time, a number of miners, not wishing to remain idle, now spend a significant amount of time preparing farms for harvest.

The second reason is that ASM seems to be readily 'integratable' into the typical Northern Ghanaian household, the organizational dynamics of which Al-Hassan and Poulton (2009) discuss at length. In all three Northern regions of the country, a 'household' is a complex extended family unit, focused on a 'compound', where the head (typically male) lives with his wife/wives, sons and extended family. Functioning on the basis of there being 'strength in numbers', the compound helps to buffer against household poverty in the sparsely-populated sections of the North of Ghana: during very short rainy seasons, it has the advantage of being able to rapidly mobilize labour on the household food plot. It also is set up so that junior members (young males and females) of the extended family are able to engage in other economic activities - which, in the case of Kui, is ASM - when they are not needed by the household head on the food plot. During the course of the fieldwork, numerous junior household members were seen digging and washing gold, the revenues from which presumably 'fed back' into the compound system, further nourishing the family food plot, economically. 
Table 1: Employment details of individuals surveyed

\begin{tabular}{|l|l|l|l|l|l|l|l|l|l|}
\hline \multicolumn{2}{|l|}{ Employment (\% of individuals surveyed) } & \multicolumn{2}{l|}{$\begin{array}{l}\text { Where earnings are used (\% } \\
\text { of individuals surveyed) }\end{array}$} & \multicolumn{2}{l|}{$\begin{array}{l}\text { Preferred Occupation (\% of individuals } \\
\text { surveyed) }\end{array}$} \\
\hline $\begin{array}{l}\text { Households } \\
\text { engaged in } \\
\text { both } \\
\text { mining and } \\
\text { farming }\end{array}$ & $\begin{array}{l}\text { Farming } \\
\text { only }\end{array}$ & $\begin{array}{l}\text { Mining } \\
\text { only }\end{array}$ & $\begin{array}{l}\text { Services } \\
\text { (blacksmithing, } \\
\text { catering, etc.) }\end{array}$ & $\begin{array}{l}\text { Farming } \\
\text { activity } \\
\text { declining } \\
\text { relative to } \\
\text { mining }\end{array}$ & $\begin{array}{l}\text { Money from } \\
\text { mining } \\
\text { funding } \\
\text { farming }\end{array}$ & Farming & Mining & Both & Other \\
\hline 22 & 34 & 28 & 16 & 65 & 35 & 48.7 & 28.7 & 11.1 & 17.4 \\
\hline
\end{tabular}

\section{Curbing Migration and Promoting Education}

Apart from providing individual households with a much-needed source of supplementary income, the evidence points to ASM being able to catalyze economic growth by curbing migration, a problem which, again, has plagued and inhibited development in the North of Ghana since the colonial period. In fact, in Northern Ghanaian towns such as Kui, the emergence of ASM has, rather unexpectedly, fuelled in-migration. This could prove integral in restoring a skills-base which, in all three of the Ghana's northernmost regions, has deteriorated over the course of the past century. During this time, scores of skilled residents and youth have migrated south in search of more remunerative employment.

The exodus began in the early 1900s, when the British Colonial Government turned to the North which, as Plange (1979b, p. 672) explains, it saw at the time 'as a labour reserve' to source manpower for various development initiatives in the South, including an array of public works, railway construction projects along the coast, agricultural projects across the Western Region and Ashanti Region, and large-scale gold mines in the towns of Obuasi and Tarkwa. The North-South migration was initially seasonal but soon became permanent, marked by the launch of recruitment campaigns by chiefs and government officers for the mines, which began as early 1907, and the rapid growth in demand for labour on cocoa 
farms, 'the remarkable growth' of which in the Ashanti Region in the colonial period is attributed 'in a large measure, to labour supplied from the Northern Territories' (Ladouceur, 1979, p. 48). This stymied the North's development:

Conclusively, there was a depletion of the young and able-bodied population, with a direct impact on the productive capacity of house-holds and communities, gradually creating the need for some cash to complement the diminishing returns in subsistence productivity. The onus then was on the outgoing migrant to send a remittance so that the family could survive more comfortably. [Plange 1979b, p. 672]

But few funds ever reached migrants' villages of origin. Whilst returning workers brought savings with them, as Ladouceur $(1979$, p. 49) explains, '[these] earnings were meager in the first place and expenses in the South were high, and [therefore] little remained when the men reached home'. With insufficient monies available to even invest in subsistence agriculture, Northern Ghanaian towns have long struggled to reduce outmigration, which again, has 'drained the North of its youngest and most able-bodied men, who...therefore [have not been] available for development in the Territory itself'.

The emergence of ASM has - rather unexpectedly - not only helped to reduce the outflow of people from the North of Ghana but has also attracted numerous people to many of its remote, semi-arid localities such as Kui. Over 92 per cent of people interviewed in Kui claimed to be migrants, a large share of whom originate from other (larger) northern localities such as Jirapa, Bole, Wa and Bolgatanga (Figure 3). Most of these migrants explained that they had moved to Kui to secure employment in the locality's growing ASM sector. Awimbula and Tsikata (2007) were the first to reflect critically on the implications of ASMinduced migration to Northern Ghanaian localities, reflecting on findings from communitylevel survey work undertaken in gold processing and extraction areas of Talensi-Nabdam District near Bolgatanga, the capital of the country's Upper East Region:

Whereas sponsors, buyers, and to some extent ghetto owners tend to be migrants from outside the region and in the case of sponsors and buyers could include other nationals 
such as Lebanese and Burkinabes, the workers at the lower scale (loco boys, kaimen and shanking ladies) tend to be locals. Even among the mine workers, the dynamiters and chisellers who required some expertise in mining tend to be southerners, while the loco boys, kaimen and shanking ladies, requiring no specific training and earning the lowest returns, tend to be mainly locals...Miners with requisite training and skills could move between various mining roles... [p. 7]

The authors are somewhat critical of this migration, arguing how it has 'resulted in technology transfer but also reproduced certain patterns of labour relations which were disadvantageous to locals'. But since undertaking their research, the dynamics of TalensiNabdam's ASM operations have changed considerably. Research since carried out in the locality (Hilson 2010; Hilson 2012) has revealed that presently, all of the mine concession owners operating in the main gold mining area, Yale or Yele, are indigenous to the area; these ASM activities, which employ more than 20,000 people, have spawned a series of downstream industries, including equipment repair and transportation services; and most importantly, hundreds of "loco boys" ${ }^{5}$ have acquired skills, steadily moving up the mine labour-hierarchy into more well-paid positions and in the process, improving their quality of life.

\footnotetext{
${ }^{5}$ Individuals who transport blasted rock from mine pits to the surface.
} 


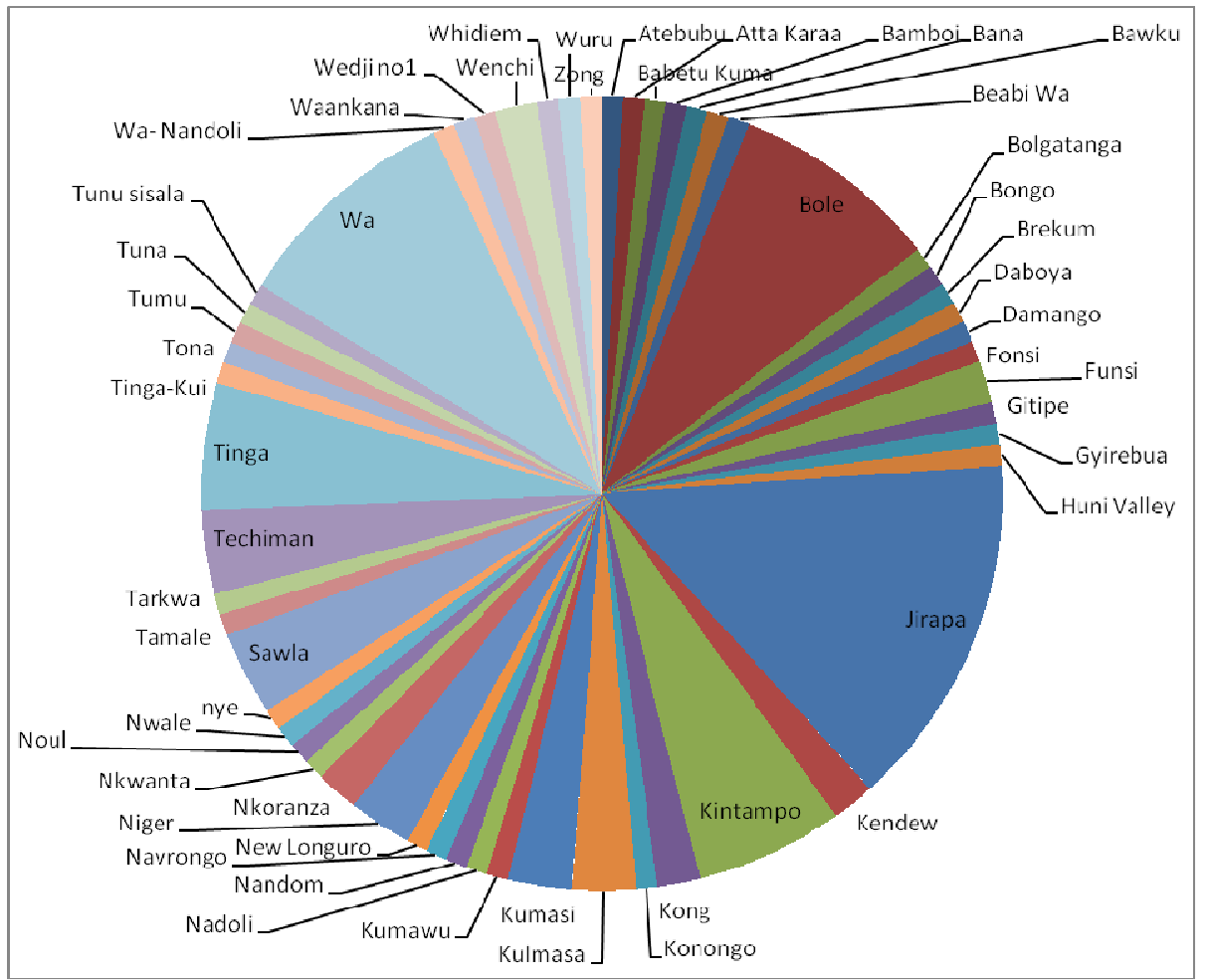

Figure 3: Origins of people living in Kui

Much of the same appears to be unfolding in Kui. Significantly, migrants who were the beneficiaries of mine technology transfer in towns such as Talensi-Nabdam have brought with them this knowledge, which has proved integral in expanding gold extraction and processing activities in the locality. There was considerable optimism among interviewees that ASM could 'normalize' the locality's population dynamics to the point where the Bole District Assembly could be in a position to allocate more funds toward the resuscitation of defunct local educational facilities.

This, however, will by no means be straightforward; restoring the foundation for education in Kui promises to be an onerous task. The source of this problem can also be traced back to the colonial period, specifically to Guggisberg's tenure as Governor of the Gold Coast. Whilst Guggisberg's administration did raise the teaching standards of the colony considerably, it further alienated the North and other marginalized areas of present- 
day Ghana through its bottom-up strategy for primary educational development (Bening, 1990). Specifically, a policy emphasizing quality and selective expansion would exclude much of Northern Ghana, which, because of its low population density, received few teachers and educational facilities (Akyeampong et al., 2007). As explained by Thomas (1974), when, in 1921, the chief commissioner forwarded requests for schools to be constructed at Bawku, Zuarungu, and Sandema and Bole (where again, Kui is located), he was told by Guggisberg himself that this was not possible on account of there being no money and that the priority at the time was developing a new school at Achimota in Accra. The Nkrumah Government attempted to address the problem by launching a special scholarship scheme (from primary to tertiary), which covered tuition fees, boarding, lodging, supplies and transport, specifically for children in the North (Akyeampong et al., 2007). Whilst this, and subsequent efforts aimed at bridging the country's North-South educational gap have had some impact, the divide remains significant. In the Northern Region today, there are 100,000 children aged 12-14 who are not in school, and only 15 per cent of its young boys and girls in the 'poor' quintile finish their primary education compared to the national average of 42 per cent (Casely-Hayford and Ghartey, 2007). There is educational foundation on which to hinge efforts such as the Capitation Grant, a landmark initiative which effectively abolished school fees at state schools, from kindergarten through to JSS. ${ }^{6}$

The challenge, therefore, lies in changing the mindsets of - likely discouraged and disengaged - residents in underdeveloped Northern Ghanaian localities about formal education. In Kui itself, schooling would likely have little impact on its current occupants, few of whom again, have finished primary school. Most of the interviewees who indicated

\footnotetext{
${ }^{6}$ Under the Capitation Grant and School Feeding Program, both of which were launched in 2005, initially on a pilot basis, each public kindergarten, primary school and Junior Secondary School is provided with close to US\$3 per student per annum to cover fees and other expenses.
} 
that financial constraints have prevented them from completing or furthering their education explained that they have no time for schooling: that the priority now is supporting their families. But a change in attitude towards education amongst current residents would certainly benefit the next generation of Kui's inhabitants (these people's children) whose fate will be heavily determined by action taken today. As indicated, a vibrant ASM sector has provided economic stability to low-skilled families in Kui and in the process, helped to improve their food security dramatically. The research confirmed that many ASM-farm families in Kui now find themselves in a - what was once a previously-unthinkable - position to critically reflect on the value of an education for their children, which bodes well for the locality's future.

The story of one interviewee, 'Kate', was particularly revealing, and fairly representative of the experiences of interviewees. After the death of her husband, Kate assumed control of the household, which has required her to manage ASM activities, something that the family has been involved in for more than five years. She has managed to accumulate enough money to send her children to private schools far superior to the local deteriorated facilities covered by the Capitation Grant. Her children live in Bole, where they attend school, whilst she resides in Kui, where she carries out ASM work. She does not want her children to live in Kui; nor does she want them to be miners. Such selflessness among family heads - namely, the willingness to make sacrifices to put children in as best a position as possible to access a quality education - will be needed if Northern Ghanaian localities such as Kui are to develop. Most people interviewed shared similar stories, explaining how the revenue generated from ASM has facilitated access to a suite of educational options for their children. The low percentage of young boys and girls engaged in ASM in Kui (less that 2 per cent of its ASM workforce is below the age of 15) could be a sign that the mindset toward education is changing. 
To summarize, the research undertaken in Kui thus far suggests that ASM could catalyze significant growth in Northern Ghana. The sector is providing numerous Northern Ghanaian societies with a platform for development that the colonial administration neglected to establish and which subsistence agriculture carried out in harsh climatic conditions is incapable of mobilizing - at least on its own. The challenge now is to reorient policy to better reflect ASM's growing importance in the North of Ghana.

\section{Discussion and Conclusion: Overhauling an Antiquated Policy Agenda}

The findings reported in this paper, generated from pilot research conducted in the locality of Kui, demonstrate that the emergence of ASM in Northern Ghana is providing a much-needed economic boost in many of its deprived areas. These findings reinforce the mainly-understated and often implied - position of a number of scholars (e.g. Awimbula and Tsikata 2007; Hilson 2010) on the importance of ASM in arid, sparsely populated sections of the North of Ghana: that it is alleviating hardship and providing incomes which are helping to nourish subsistence agriculture and in the process, improving food security. The ASM sector has fast become a focus in the livelihoods of tens of thousands of families in rural stretches of Northern Ghana, helping to establish a foundation for development that has long been missing. Whilst there is certainly ample evidence that underscores ASM's importance here and elsewhere in sub-Saharan Africa, policymakers and donors have yet to embrace the idea that activities can have a positive impact on local economic development. Continued clinging to antiquated ideas, including the belief that the sector is populated exclusively by rogue entrepreneurs looking to 'get rich quick', has proved to be a formidable barrier to ASM's inclusion in donor programs. 
For ASM in villages such as Kui to be supported by the government, significant change would need to be made in three areas, the first being the general policy stance toward the industry in the country; this would need to be radically overhauled. Since 1989, there has been a licensing system in place for ASM but it has proved highly inappropriate for the poverty-driven groups which mostly populate the sector. Rather than providing empowerment and security of tenure, the system has further marginalized informal operators, requiring the prospective licensee to make a number of costly payments; wait significant periods of time for decisions on applications; and effectively 'kick-start' the process himself/herself, which requires numerous - often costly - visits to various ministries in Accra (Hilson and Potter 2005; Tschakert and Sinha 2007). The response of the Ghanaian Government to general concerns voiced by officers at the International Labour Organization (ILO) over a decade ago about the inadequacies of ASM licensing in sub-Saharan Africa has been lukewarm at best. ${ }^{7}$ The government has simply not fixed what is clearly a bureaucratic licensing system for ASM; nor does it even acknowledge that it is much of a problem, despite the burgeoning body of evidence which points to the sector being largely poverty-driven countrywide, populated by people who lack the finances and logistical means to travel to Accra and make costly payments for licenses (e.g. Amankwah and Anim-Sackey 2003; Banchirigah 2008; Hilson 2010).

It seems inexplicable how, despite this evidence, little the Ghanaian Government's position on and approach to managing ASM has changed over the past two decades, a period during which even large donors such as the World Bank and various departments of the United Nations have softened their stances considerably toward the sector and have started to

\footnotetext{
${ }^{7}$ The chief concern voiced being 'if small-scale mining is to be encouraged to operate legally, legislation must be (at least) even-handed in allowing small-scale miners access to suitable land for prospecting and mining activities', and 'must be "user friendly" as far as the issuing of permits and the granting of licences are concerned - permits that provide clear security of tenure for a reasonable period' (ILO, 1999, np).
} 
embrace the idea that it is often poverty-driven. It could be a case that policies remain heavily disconnected from the realities on the ground because of institutional memory. Many of the government officials who now occupy senior-level positions in Accra and are charged with, inter alia, making decisions on applications for licenses and crafting policies for the sector, were field officers 15-20 years ago, a time when ASM was largely populated by individuals looking to 'get-rich quick'. This view has been shaped heavily by the Brazilian garimpeiro gold rushes in the early-1980s and the more recent diamond-fuelled wars in the likes of Sierra Leone; the idea of the sector being poverty-driven had not yet gained currency in policymaking and donor circles. It may, therefore, be a case of these officials having moved into senior-level positions without witnessing or having taken the time to diagnose for themselves why ASM populations have mushroomed over the past decade. Scholars (e.g. Hilson and Potter 2005; Banchirigah, 2006) have since demonstrated that, the rapid increase in the country's ASM population at this time was linked heavily to the hardship and unemployment that surfaced under structural adjustment and reform, the impact of which was still being debated two decades ago. The occupation of senior-level government posts by such individuals could explain why antiquated views about unlicensed ASM - including it being a 'menace' to society, populated by criminals and led by individuals who deliberately evade regulations ${ }^{8}-$ continue to resonate strongly in the local media and policymaking circles.

The second area in need of change is the approach being taken to alleviate rural poverty, which is perhaps even more antiquated than ASM policy. The challenge here is twofold. First - and indeed the most significant change needed - ASM must start receiving

\footnotetext{
${ }^{8}$ http://www.ghana-mining.org/ghanaims/SectorNews/NewsArchivesJUL2011/tabid/231/Default.aspx, http://ghanadistricts.com/news/?read=42436, http://www.ghanabusinessnews.com/2011/10/12/mineralscommission-to-take-on-galamsey-operators/ (Accessed 10 May 2012).
} 
priority policy treatment in the country's rural poverty alleviation strategy. There were signs, nearly a decade ago, that such change was on the horizon, following publication of Ghana's first Poverty Reduction Strategy Paper (PRSP), An Agenda for Growth and Prosperity. The document states, unequivocally, that 'Current mining laws tend to disproportionately favour large-scale mining enterprises' and that in order 'To address this apparent imbalance, measures will be put in place to expand the scope and increase the support to the small and medium scale sub-sector with the view to making it the predominant means of exploiting minerals in the long term' (IMF, 2003, p. 91). It was one of the most comprehensive policy statements conceived in response to the ILO's call for legislation (for ASM) to be more 'even-handed' (ILO, 1999). But very little progress has since been made on this front. In fact, the policy stance toward ASM has regressed: in the country's most recent PRSP (IMF, 2006), Growth and Poverty Reduction Strategy (GPRS II) (2006 - 2009), the sector is not even mentioned. The discussion on mining in this document focuses exclusively on mechanized large-scale activity, praising the efforts made up to the time of its publication to bolster foreign investment in exploration and mining projects. It states that 'Growth in the mining sub-sector [of Ghana], particularly gold, was largely due to substantial infusion of capital from both local and external sources aided by the stable environment created by the institution of policies that have insulated earnings and costs from foreign exchange controls', a clear indication of the country's hitherto large-scale mining policy bias.

The additional challenge relates to refocusing rural development strategies altogether. Most advocate intensified support to subsistence agriculture as the solution to the country's rural poverty problem. Notably, GPRS II (IMF, 2006) champions 'Agriculture as a Basis for Economic Growth and Structural Transformation' on the basis of it being 'the highest contributor to GDP and provid[ing] employment for over 60 per cent of the population', with the view that 'growth in the sector will impact directly on growth of the economy as well as 
employment' (p. 23). In a number of localities across rural sub-Saharan Africa, however, families are 'branching out' of smallholder farming because it is incapable of sustaining them on its own, economically. Even if plans to intensify support to smallholder farming were to materialize, how do host governments and donors expect rural subsistence families to compete in a liberalized agricultural market? Under reform, access to resources and expertise has also proved challenging for smallholders across the region: crucial inputs such as fertilizers are no longer subsidized, and most support services have been systematically dismantled or privatized (after Crisp and Kelly, 1999). Using data on agriculture's contribution to GDP and estimated employment figures in the sector to justify a farm-first strategy to rural development is highly-questionable because they fail to provide the complete picture. As Banchirigah and Hilson (2010) explain, the former was never intended as a measure of quality of life, although it is continuously used in this fashion, and the latter are more likely an indication of the number of people engaged as opposed to employed in farm activities. Using these data to inform rural development strategy can potentially paint an inaccurate picture of a rural setting and yield inappropriate policy interventions. But with sub-Saharan Africa-wide initiatives, notably the African Union's New Partnership for African Development (NEPAD), being heavily underpinned by the same ideas, implementing a radically re-orientated rural development agenda in which ASM receives greater priority and smallholder agriculture is de-emphasized, could prove challenging in Ghana.

The third and final area in need of change is the development strategy of Northern Ghana itself. Localities such as Kui have little chance of escaping poverty and developing unless more dynamic policies and interventions are designed and implemented. The Ghanaian Government seems to recognize that the poverty plaguing the North is in need of immediate attention, indicating, in the country's inaugural PRSP (IMF, 2003) that: 
Five out of ten regions in Ghana had more than $40 \%$ of their population living in poverty in 1999. The worst affected being the three northern savannah regions (the Upper East, Upper West and Northern Regions). Nine out of ten people in the Upper East; eight out of ten in Upper West, seven out of ten in Northern Region...[p. ii]

It goes on to suggest that to correct this problem, funding priorities must change because 'Expenditure has continued to be biased against development of the rural environment and has failed to ameliorate disparities between north and south' (p. 2). As a solution to the problem, however, the Ghanaian Government has also called for the intensification of support to rural families, failing to recognize how climatic conditions limit what can be achieved in the area of agricultural production and how families are transitioning out of farming. In Kui and surrounding areas, there are numerous community development projects being undertaken, some of which are listed on the Bole District website. ${ }^{9}$ But the developmental impact of these efforts, which include the construction of community centres, the dissemination of agricultural implements and the construction of a rural technology facility, is bound to be negligible because few target the root of the poverty problem plaguing the district. This oversight extends beyond government circles. Even many of the NGOs that supposedly have a strong presence in the very Northern communities in need of assistance and where ASM has rapidly overtaken farming as the primary income-earning activity are also lobbying for a blueprint of agriculture-led growth. Notable among these is SENDGhana, an NGO established in 1998 which seeks to 'accelerate the socio-economic development of the Savannah belt through strategic investment in resource development' ${ }^{10}$ In line with the Government's vision of the country's Northern Territories, the NGO is

\footnotetext{
${ }^{9}$ http://bole.ghanadistricts.gov.gh/?arrow=dev\&_=81 (accessed 14 April 2012).

${ }^{10} \mathrm{http}: / / \mathrm{www}$. sendwestafrica.org/west/index.php?option=com_content\&view=article\&id=61:savannaaccelerated-development-authority-sada-funded-programmes\&catid=38:programmes\&Itemid=73 (Accessed 15 March 2012).
} 
working to develop a 'Forested North' by 2030, where 'agricultural production of is modernised and oriented towards a larger market'.

It may be unrealistic to expect any change to take place in the aforementioned three areas in the short term. But as evidence underscoring ASM's importance in Ghana's rural economy and the inappropriateness of poverty alleviation strategies in its Northern Territories begins to mount, the government and donors will no doubt be pressured to revise its policy approach. If poverty in rural Northern localities such as Kui is to be tackled effectively, more innovative solutions will be needed. The problem in Ghana is that, over the past 20-30 years, whilst the dynamics of communities have changed dramatically, rural development strategy has remained static: since enacting its Vision 2020 nearly two decades ago, the same agriculture-led development approach to rural poverty has dominated the policy agenda, innovatively repackaged in successive PRSPs. Moreover, the country's flagship Ghana Living Standards Survey has failed to generate any new data, failing abysmally to capture how the dynamics of deprived rural communities have changed during this period. One of the most significant oversights is failure to acknowledge the growing importance of ASM in many rural areas of the country, and how for tens of thousands of families, it is now a primary income-earning activity.

Although - and especially in the case of the North of the country - a revamped poverty alleviation strategy which prioritizes support for ASM would clearly have a greater developmental impact in the current environment, this would take some time to legitimize and launch. Given the lack of commercial interest in its arid landscape, the North of Ghana would be the ideal setting to implement an ASM-led development strategy. As the case of Kui has shown, in Northern Ghana, the movement into ASM has alleviated significant hardship at the household level. Perhaps more importantly, ASM seems to have bolstered the economies of many Northern localities by helping to reduce the migration that has crippled 
the Northern Region, Upper West Region and Upper East Region of Ghana for generations. Specifically, a rapidly-expanding ASM sector has helped to stabilize the populations of Northern Ghanaian towns such as Kui, putting many District Assemblies (local government) in a position to plan 'generationally' for the first time. Continuing to downplay ASM's importance in Northern Ghana would be counterproductive. 


\section{References}

Abdulai, A., CroleRees, A. 2001. Determinants of income diversification amongst rural households in Southern Mali. Food Policy, 26(4), 437-452.

Akyeampong, K., Djangmah, J., Oduro, A., Seidu, A., Hunt, F. 2007. Access to Basic Education in Ghana: The Evidence and the Issues. Consortium for Research on Educational Access, Institutions and Equity, UK Department for International Development (DFID), London.

Al-Hassan, R., Poulton, C. 2009. Agriculture and Social Protection in Ghana. FAC Working Paper Series, Future Agricultures, UK.

Amankwah, R. K., Anim-Sackey, C. 2003. Strategies for sustainable development of the small-scale

gold and diamond mining industry of Ghana. Resources Policy, 29(3-4): 131-138.

Aryee, B. N. A., Ntibery, B.K., Atorkui, E. 2003. Trends in the small-scale mining of precious minerals in Ghana: a perspective on its environmental impact. Journal of Cleaner Production 11(2): 131-140.

Awumbila, M., Tsikata, D. 2007. Migration dynamics and small scale gold mining in northeastern Ghana: implications for sustainable rural livelihoods. Fifth African Population Conference, Union for African Population Studies, 10-14 December 2007 Arusha, Tanzania.

Banchirigah, S.M. 2006. How have reforms fuelled the expansion of artisanal mining? Evidence from Sub-Saharan Africa. Resources Policy 31 (3): 165-171.

Banchirigah, S.M. 2008. Challenges with eradicating illegal mining in Ghana: a perspective from the grassroots. Resources Policy, 33(1): 28-37.

Banchirigah, S.M., Hilson, G. 2010. De-Agrarianization, Re-Agrarianization and Local Economic Development: Re-Orientating Livelihoods in African Artisanal Mining Communities. Policy Sciences 43(2): 157-180.

Barrett, C.B., Reardon, T., Webb, P. 2001. Nonfarm income diversification and household livelihood strategies in rural Africa: Concepts, dynamics, and policy implications. Food Policy 26(4): 315-331

Batterbury, S. 2001. Landscapes of diversity: A local political ecology of livelihood diversification in South-Western Niger. Ecumene 8(4): 437-464.

Bening, R. B. 1990. A History of Education in Northern Ghana, 1907-1976. Ghana University Press, Accra.

Berry, S. 1989. Social institutions and access to resources. Africa 59(1): 41-55.

Bigsten, A. Tengstam, S. 2011. Smallholder diversification and income growth in Zambia. Journal of African Economies 20(5): 781-822. 
Bryceson, D.F. 1996. Deagrarianization and rural employment in sub-Saharan Africa: A sectoral perspective. World Development 24(1):97-111.

Calsey-Hayford, L., Ghartey, A.B. 2007. The Leap to Literacy and Life Change in Northern Ghana. School for Life Program, Government of Ghana, Accra.

Crisp, B., Kelly, M. 1999. The socioeconomic impacts of structural adjustment. International Studies

Quarterly 43: 533-552.

Ellis, F. 1998. Survey article: Household strategies and rural livelihood diversification. The Journal of Development Studies 35 (1):1-38.

Ellis, F. 2000. Rural Livelihoods and Diversity in Developing Countries. Oxford University Press, Oxford.

Ellis, F., Bahiigwa, G. 2003. Livelihoods and rural poverty in Uganda. World Development 31(6): 997-1013.

Elimqvist, B., Olsson, L. 2006. Livelihood diversification: Continuity and change in the Sahel. GeoJournal 67(3): 167-180.

Fabusoro, E., Sodiya, C.I. 2011. Institutions for collective action among settled Fulani agropastoralists in Southwest Nigeria. Journal of Agricultural Education and Extension 17(1): 53-68.

Fisher, E. 2007. Occupying the margins: labour integration and social exclusion in artisanal mining in Tanzania. Development and Change, 38(4), 735-760.

Ghana Statistical Services. 2000. Ghana Living Standards Survey: Report of the Fourth Round. Ghana Statistical Services, Accra.

Ghana Statistical Services. 2008. Ghana Living Standards Survey: Report of the Fifth Round. Ghana Statistical Services, Accra.

Gueye, D. 2001. Small-scale mining in Burkina Faso. Mining, Minerals and Sustainable Development

(MMSD) Working Paper 73. London: International Institute for Environment and Development

(IIED).

Hilson, G. 2010. Challenges with Eradicating Child labour in the Artisanal Mining Sector: Experiences from Northern Ghana. Development and Change 41(3): 445-473.

Hilson, G. 2012. Poverty traps in small-scale mining communities: The case of sub-Saharan Africa. Canadian Journal of Development Studies (accepted for publication). DOI:10.1080/02255189.2012.687352

Hilson, G., Potter, C. 2005. Structural adjustment and subsistence industry: Artisanal gold mining in Ghana. Development and Change 36(1): 103-131. 
International Labour Organization (ILO). 1999. Social and labour issues in small-scale mines. Report for discussion at the Tripartite Meeting on Social and Labour Issues in Smallscale Mines. Geneva: International Labour Office.

International Monetary Fund (IMF). 2003. Ghana poverty reduction strategy 2003-2005: An agenda for growth and prosperity. International Monetary Fund, Washington DC.

International Monetary Fund (IMF). 2006. Ghana growth and poverty reduction strategy paper. International Monetary Fund, Washington DC.

Jaques, E., Zida, B., Billa, M., Greffie, C., \& Thomassin, J. F. 2006. Artisanal and smallscale gold mines in Burkina Faso: Today and tomorrow. In G. M. Hilson (Ed.), Small-scale mining, rural subsistence and poverty in West Africa. PracticalAction Publications, Rugby.

Keita, S. 2001. Study on Artisanal and Small-Scale Mining in Mali. Mining, Minerals and Sustainable Development (MMSD) Working Paper 80. London: International Institute for Environment and Development (IIED).

Kimble, David. 1971. A Political History of Ghana: The Rise of Gold Coast Nationalism, 1850-1928. Oxford University Press, London.

Ladouceur, P.A. 1979. Chiefs and Politicians: The Politics of Regionalism in Northern Ghana. Longman, London.

Laube, W., Schraven, B., Awo, M. 2012. Smallholder adaptation to climate change: Dynamics and limits in Northern Ghana. Climatic Change 111(3): 753-774.

Little, P., Aboud, A., Lenachuru, C. 2009. Can formal education reduce risks for droughtprone pastoralists?: A case study from Baringo District, Kenya. Human Organization 68(2): 154-165.

Maconachie, R., Hilson, G. 2011. Safeguarding livelihoods or exacerbating poverty?: Artisanal mining and formalization in West Africa. Natural Resources Forum 35(4): 293303.

Pedersen, J., Benjaminsen, T.A. 2008. One leg or two? Food security and pastoralism in the northern Sahel. Human Ecology 36(1): 43-57.

Plange, N.K. 1979a. Underdevelopment in Northern Ghana: natural causes or colonial capitalism? Review of African Political Economy 6(15-16): 4-14.

Plange, N.K. 1979b. 'Opportunity cost' and labourmigration: a misinterpretation of proletarianisation in northern Ghana. Journal of Modern African Studies 17(4): 655-676.

Reardon, T., Delgado, C., Malton, P. 1992. Determinants and effects of income diversification in Burkina Faso. Journal of Development Studies 28(2): 264-296.

Siegel, S., Veiga, M. 2009. Artisanal and small-scale mining as an extralegal economy: De Soto and the redefinition of formalization'. Resources Policy, 34 (1-2), 51-56. 
Smith, K., Barrett, C.B., Box, P.W. 2001. Not necessarily in the same boat: Heterogeneous risk assessment among east African pastoralists. Journal of Development Studies 37(5): 1-30.

Snyder, R. 2006. Does lootable wealth breed disorder? A political economy of extraction framework. Comparative Political Studies 39(8): 943-968.

Thomas, R. G. 1974. Education in Northern Ghana, 1906-1940: A Study in Colonial Paradox. The International Journal of African Historical Studies 7(3): 427-467.

Thornton, P.K., Boone, R.B., Galvin, K.A., BurnSilver, S.B., Waithaka, M.W., Kuyiah, J., Karanja, S., Gonzalez-Estrada, E., Herrero, M. 2007. Human Ecology 35(4): 461-476.

Tschakert, P., Singha, K. 2007. Contaminated identities: Mercury and marginalization in Ghana's artisanal mining sector. Geoforum 38: 1304-1321.

West, C.T. 2009. Domestic transitions, desiccation, agricultural intensification, and livelihood diversification among rural households on the Central Plateau, Burkina Faso. American Anthropologist 111(3): 275-288.

World Bank. 2005. The millennium development goals and small-scale mining: A conference for forging partnerships for action. Workshop Report. The World Bank, Washington DC.

World Bank. 2011. Republic of Ghana: Tackling Poverty in Northern Ghana. World Bank Report No. 53991-GH, World Bank, Washington DC.

Wouterse, F., Taylor, J.E. 2008. Migration and income diversification: evidence from Burkina Faso. World Development 36 (4): 625-640.

Wren, S., Speranza, C.I. 2010. The struggle to diversity rural livelihoods: Bio-enterprise initiatives and their impacts on agro-pastoralists and pastoralists communities in the drylands of Kenya. European Journal of Development Research 22(5): 751-769.

Yaro, J.A. 2006. Is deagrarianisation real? A study of livelihood activities in rural northern Ghana. Journal of Modern African Studies 44(1): 125-156.

Yaro, J.A. 2010. Customary tenure systems under siege: Contemporary access to land in Northern Ghana. Geojournal 75 (2): 199-214 